REVIEW

\title{
Hypogonadism as a risk factor for cardiovascular mortality in men: a meta-analytic study
}

\author{
Giovanni Corona ${ }^{1,2}$, Giulia Rastrelli ${ }^{1}$, Matteo Monami ${ }^{3}$, André Guay ${ }^{4}$, Jaques Buvat ${ }^{5}$, Alessandra Sforza ${ }^{2}$, \\ Gianni Forti ${ }^{6}$, Edoardo Mannucci ${ }^{3}$ and Mario Maggi ${ }^{1}$ \\ ${ }^{1}$ Sexual Medicine and Andrology Unit, Department of Clinical Physiopathology, University of Florence, Viale Pieraccini 6, 50139 Florence, Italy, \\ ${ }^{2}$ Endocrinology Unit, Medical Department, Azienda Usl Bologna Maggiore-Bellaria Hospital, Bologna, Italy, ${ }^{3}$ Diabetes Section Geriatric Unit, Department \\ of Critical Care, University of Florence, Florence, Italy, ${ }^{4}$ Center For Sexual Function/Endocrinology, Lahey Clinic, Peabody, Massachusetts, USA, ${ }^{5}$ Centre \\ d'Etude et de Traitement de la Pathologie de l'Appareil Reproducteur et de la Psychosomatique, Lille, France and ${ }^{6}$ Endocrinology Unit, Department of Clinical \\ Physiopathology, University of Florence, Florence, Italy \\ (Correspondence should be addressed to M Maggi; Email: m.maggi@dfc.unifi.it)
}

\begin{abstract}
Objective: To verify whether hypogonadism represents a risk factor for cardiovascular (CV) morbidity and mortality and to verify whether testosterone replacement therapy (TRT) improves CV parameters in subjects with known CV diseases (CVDs).

Design: Meta-analysis.

Methods: An extensive Medline search was performed using the following words 'testosterone, CVD, and males'. The search was restricted to data from January 1, 1969, up to January 1, 2011.

Results: Of the 1178 retrieved articles, 70 were included in the study. Among cross-sectional studies, patients with CVD have significantly lower testosterone and higher 17- $\beta$ estradiol $\left(\mathrm{E}_{2}\right)$ levels. Conversely, no difference was observed for DHEAS. The association between low testosterone and high $\mathrm{E}_{2}$ levels with CVD was confirmed in a logistic regression model, after adjusting for age and body mass index (hazard ratio $(\mathrm{HR})=0.763(0.744-0.783)$ and $\mathrm{HR}=1.015$ (1.014-1.017), respectively, for each increment of total testosterone and $\mathrm{E}_{2}$ levels; both $\left.P<0.0001\right)$. Longitudinal studies showed that baseline testosterone level was significantly lower among patients with incident overall- and CV-related mortality, in comparison with controls. Conversely, we did not observe any difference in the baseline testosterone and $\mathrm{E}_{2}$ levels between case and controls for incident CVD. Finally, TRT was positively associated with a significant increase in treadmill test duration and time to $1 \mathrm{~mm}$ ST segment depression.

Conclusions: Lower testosterone and higher $\mathrm{E}_{2}$ levels correlate with increased risk of CVD and CV mortality. TRT in hypogonadism moderates metabolic components associated with CV risk. Whether low testosterone is just an association with CV risk, or an actual cause-effect relationship, awaits further studies.
\end{abstract}

European Journal of Endocrinology 165 687-701

\section{Introduction}

Cardiovascular disease (CVD) is the world's leading killer disease, and over $80 \%$ of deaths due to CVD occur in low- and middle-income countries (1). However, in all populations studied, CVD is more frequent and has a greater mortality risk in men than in women (2). In Europe, one in four men dies before the age of 75 years due to CVD, while the figure for women is only one in six. This gender-related difference is even more evident for deaths before the age of 65 years ( 12 vs $5 \%$ in men and women, respectively, see also www.heartstats.org/ temp/ESspweb08spchapter.1.pdf). For coronary heart disease (CHD), women trail men in increased incidence by 10 years, although the gap closes with advancing age (3). The reasons for such gender difference have not been completely understood (4-10). However, sex hormones have been considered as a possible factor. Premenopausal women have been thought to have decreased risk of CVD because of their estrogen dominance, and it was presumed that men had an increased risk due to their androgens, although this has never been proven scientifically. The universal excess risk of CHD in men observed above, coupled with the apparent loss of the female advantage in women who had an early menopause and to the higher CV risk profile in women with hyperandrogenism, led to the hypothesis that the effects of endogenous estrogens and androgens are beneficial or harmful respectively. Data on the role of estrogens and DHEAS in the pathogenesis of male CVD are limited. Studies on the role of testosterone as a predictor of $\mathrm{CV}$ risk in men are 
controversial. Recent evidence suggests that reduction, rather than increase, of testosterone level could be associated with higher CV risk $(1,11,12)$. However, a meta-analysis of epidemiological studies displayed no association between endogenous testosterone and risk for CVD in middle-aged men (13). This meta-analysis (which did not provide data on $17 \beta$ estradiol $\left(\mathrm{E}_{2}\right)$ and DHEAS) was limited to longitudinal (cohort) studies in middle-aged men, excluding older individuals. Clinical trials were, in fact, not considered (13). Several metaanalyses on testosterone replacement therapy (TRT) safety derived from randomized clinical trial (RCT) studies are presently available (see for review references $(1,12))$; however, they are not focused on TRT efficacy on $\mathrm{CV}$ risk in patients with documented ischemic cardiac diseases.

The aim of our meta-analysis was

i) to verify whether hypogonadism represents a risk factor for CV morbidity and mortality and

ii) to verify whether TRT improves $\mathrm{CV}$ parameters in subjects with known CVD.

We therefore performed a systematic review and meta-analysis of available cross-sectional (14-68) and prospective studies on sex steroids and CVD $(34,38,58$, 69-75). In addition, we also performed a specific metaanalysis on the potentially beneficial CV effects of TRT, as derived from the available RCTs (76-81).

\section{Methods}

A meta-analysis was performed including all prospective and cross-sectional studies, comparing testosterone levels in subjects with or without CVD. In addition, RCTs - either with a cross-over or a parallel series design enrolling patients with CVD and comparing TRT with placebo were also included, provided that they reported data on treadmill test in TRT and placebo groups. Metaanalysis on the effect of TRT on CV outcomes was limited to those trials designed to test the effect of TRT on treadmill test parameters in men with chronic stable angina. In addition, to make the results more comparable, studies not reporting hormonal parameters as continuous variables, expressed as mean \pm s.D. (or S.E.M.), were excluded.

An extensive Medline search was performed using the following words: 'testosterone, CVD, and males'. The search, which accrued data from January 1, 1969 up to January 1, 2011 was restricted to English-language articles and studies of human participants. The identification of relevant abstracts, the selection of studies based on the criteria described above, and the subsequent data extraction were performed independently by two of the authors (G Corona and G Rastrelli) and conflicts were resolved by the third investigator (M Monami). The quality of RCTs was assessed using the parameters proposed by Jadad et al. (82).
Completed but still unpublished trials were identified through a search of www.clinicaltrials.gov website and the results, when not already available on the website, were obtained through a formal request to the authors.

\section{Statistical analysis}

Heterogeneity for cross-sectional studies was assessed using the $I^{2}$ test for total testosterone (TT). Considering that heterogeneity could not be excluded $\left(I^{2}=93.50 \%\right)$, standardized mean differences in TT, sex hormonebinding globulin (SHBG), $\mathrm{E}_{2}$, and DHEAS between subjects with or without CVD were calculated using a random effect model. Meta-regression analysis was performed to test the effect of age and body mass index (BMI), diabetes, and hypertension on TT and $\mathrm{E}_{2}$ levels. In addition, linear regression analysis model, weighing each study for the number of subjects enrolled, was performed to verify the independent effect of age, BMI, and CVD on TT and $\mathrm{E}_{2}$ levels.

In longitudinal studies, after verifying heterogeneity $\left(I^{2}=98.7 \%\right)$, standardized mean differences for TT between incident cases of CVD and controls were calculated using a random effect model.

In RCTs, the lack of homogeneity $\left(I^{2}=56.3 \%\right)$ suggested the use of a random effect model to calculate the standardized difference in mean values of time to $1 \mathrm{~mm}$ ST segment depression and other treadmill test parameters.

All analyses were performed using Comprehensive Meta-analysis Version 2, Biostat (Englewood, NJ, USA) and SPSS 17.0 (Chicago, IL, USA).

\section{Results}

Of the 1178 retrieved articles, 70 were included in the study. In particular, 54, 10, and six were crosssectional, longitudinal, and interventional studies

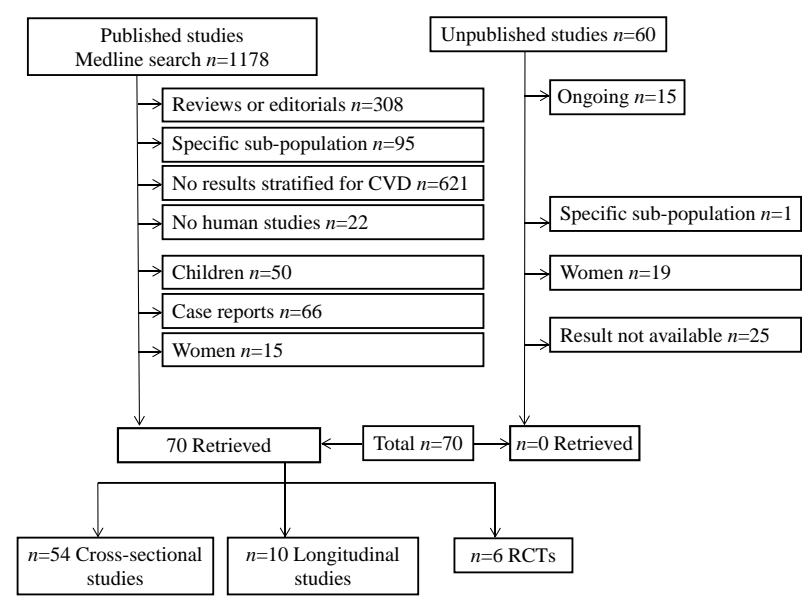

Figure 1 Trial flow diagram. CVD, cardiovascular diseases; RCTs, randomized clinical trials. 


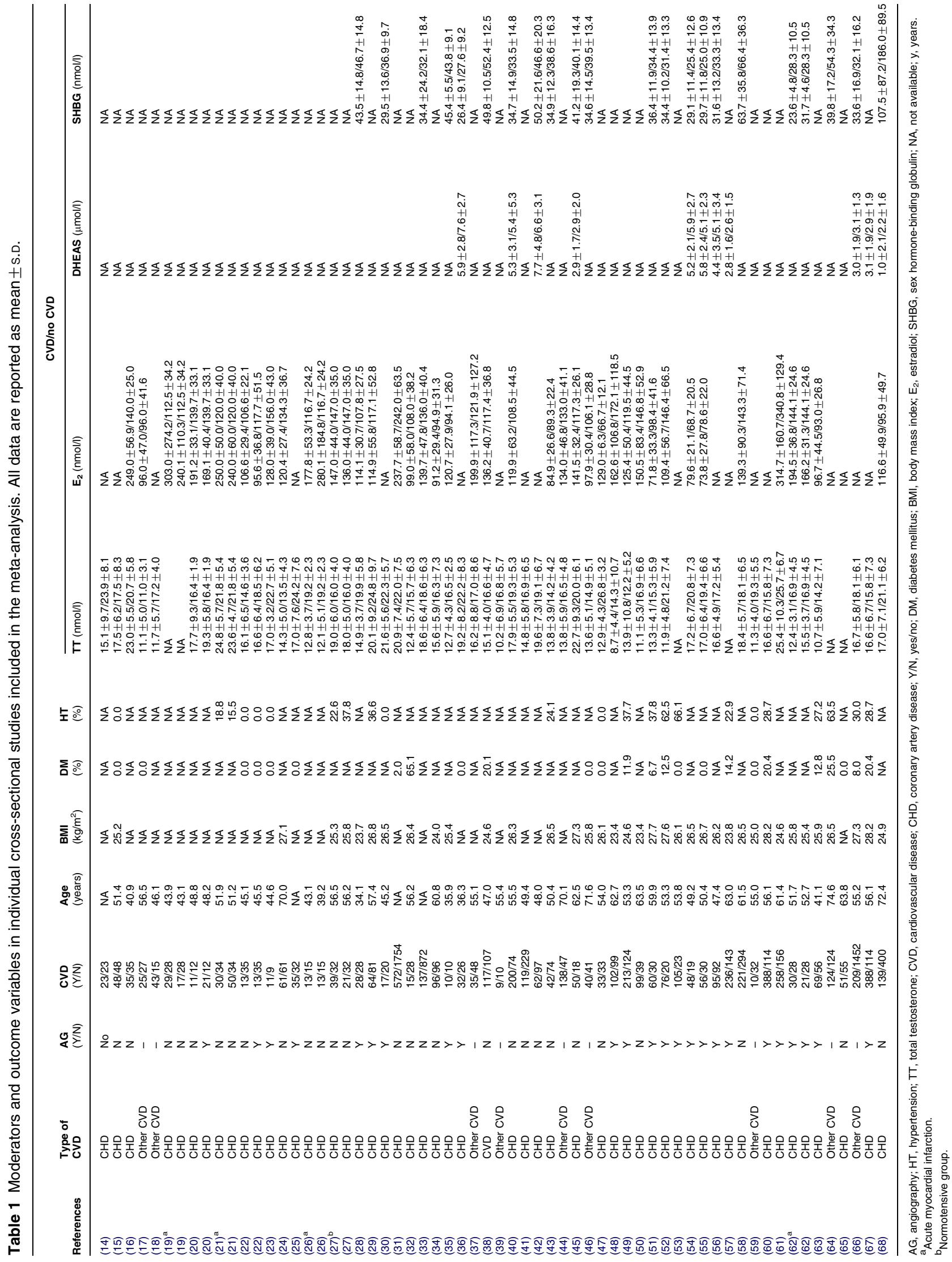


respectively (Fig. 1). The characteristics of the trials included in the meta-analysis are summarized in Tables $1-4$.

\section{Cross-sectional studies}

Among the cross-sectional studies (including 5153 CVD patients and 7513 non-CVD patients), information on TT and SHBG was available in 49 and 14 respectively. In addition, among studies evaluating TT, 25,20 , and eight studies evaluated men with nonangiographically and angiographically documented CHD or other CVD respectively. Finally, data on $E_{2}$ and DHEAS were available in 36 and 11 studies respectively.

The Begg adjusted rank correlation test (Kendall $\tau=-0.170 ; P=0.06$ ), calculated on the basis of TT in cross-sectional studies, suggested no major publication bias.

When considering data on TT, patients with any CVD showed significantly $(P<0.0001)$ lower TT plasma levels in comparison with individuals without CVD $(-2.55(-3.39,-1.71) \mathrm{nmol} / \mathrm{l})$. Similar results were obtained when analyzing separately subjects with $(P<0.0001)$ and without $(P<0.01)$ angiographically documented CHD or other CVD $(P<0.0001$, see also Fig. 2A-C). Conversely, no significant difference between patients with or without CVD was observed for SHBG and DHEAS (Table 5). No sub-group analyses for the type of CVD were performed for SHBG due to insufficient available data.

Meta-regression analysis on cross-sectional studies showed that differences in TT between patients with and without any CVD did not differ as a function of age, while they were significantly higher in obese, diabetic, and hypertensive patients, i.e. in patients with chronic diseases (Fig. 3A-D). In a logistic regression model, adjusting for age and BMI, the presence of any CVD was still associated with lower TT levels $(\mathrm{HR}=0.837$ (0.823-0.852) for each $\mathrm{nmol} / \mathrm{l}$ increment of testosterone; $P<0.0001)$. The same results were observed when diabetes and hypertension prevalence were introduced in the model, as covariates $(\mathrm{HR}=0.536$ $(0.447-0.606)$ for each $\mathrm{nmol} / \mathrm{l}$ increment of testosterone; $P<0.0001)$.

When considering data on $\mathrm{E}_{2}$, patients with any CVD showed significantly $(P<0.0001)$ higher $E_{2}$ plasma levels in comparison with subjects without CVD (25.11 (10.59-39.63) pmol/l; Fig. 4A). Similar results were obtained when only patients with CHD were considered (Fig. 4B). No sub-group analyses for the type of CHD were performed for $E_{2}$, due to insufficient data.

Meta-regression analysis on cross-sectional studies showed that differences in $\mathrm{E}_{2}$ between patients with CVD and controls were significantly lower in younger, In a logistic regression model, after adjusting for age obese, diabetic, and hypertensive patients (Fig. 5A-D).

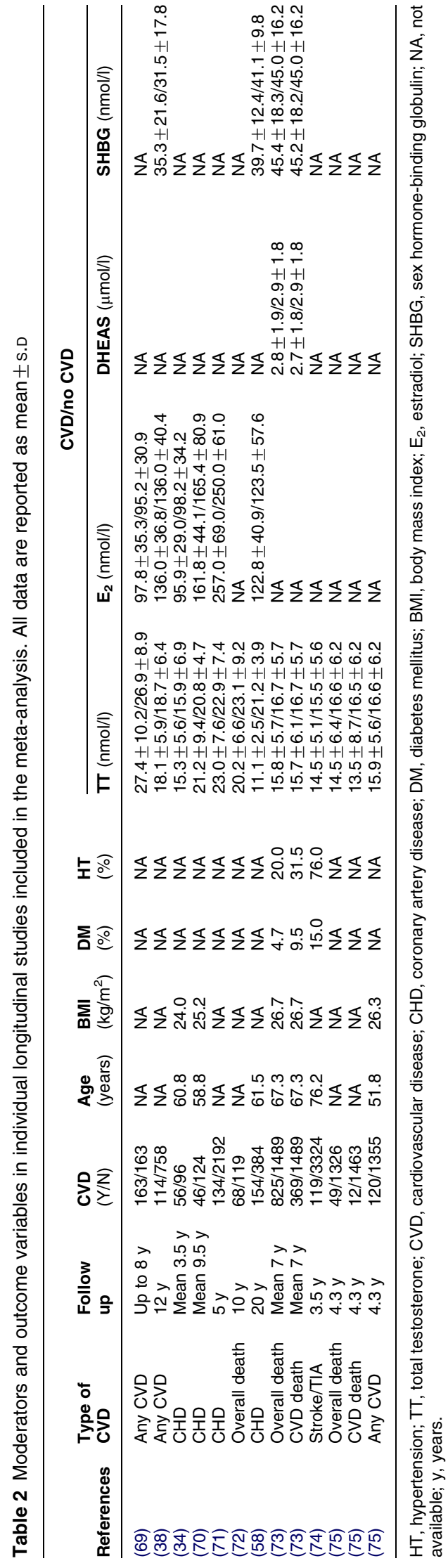

www.eje-online.org 
Table 3 Characteristics of the randomized clinical studies included in the meta-analysis.

\begin{tabular}{|c|c|c|c|c|c|c|}
\hline \multirow[b]{2}{*}{ Characteristics } & \multicolumn{6}{|c|}{ Studies (references) } \\
\hline & (76) & $(77)$ & (78) & (79) & $(80)$ & (81) \\
\hline Drug & Test. (i.v.) & Test. (i.v.) & Test. patch & Test. (i.v.) & Sustanon (i.m.) & TU (i.m.) \\
\hline Dose & $2.5 \mathrm{mg}$ once & $2.3 \mu \mathrm{g}$ once & $5 \mathrm{mg}$ daily & * & $100 \mathrm{mg}$ twice/week & $1.000 \mathrm{mg} / 12$ weeks \\
\hline Comparator & Placebo & Placebo & Placebo & Placebo & Placebo & Placebo \\
\hline Randomization & A & A & A & A & A & A \\
\hline Blinding & $A$ & A & $A$ & A & A & A \\
\hline Drop-out & A & A & A & A & A & A \\
\hline Intention to treat & Yes & Yes & Yes & Yes & Yes & Yes \\
\hline
\end{tabular}

Test., testosterone; TU, testosterone undecanoate in castor oil; A, adequate; NA, not adequate.*Testosterone doses were individualized to produce physiologic (defined as double the baseline testosterone level) or supra-physiologic $(6 \times$ baseline) serum testosterone level.

and BMI, the presence of any CVD was still associated with higher $\mathrm{E}_{2}$ levels $(\mathrm{HR}=1.002(1.003-1.004)$ for each $\mathrm{pmol} / \mathrm{l}$ increment of $\left.\mathrm{E}_{2} ; P<0.0001\right)$. Similar results were observed when TT level was introduced in the same regression model $(\mathrm{HR}=0.763(0.744-0.783)$, $P<0.0001$, and $H R=1.015$ (1.014-1.017), respectively, for each increment of TT and $\mathrm{E}_{2}$ levels; both $P<0.0001)$.

\section{Longitudinal studies}

In longitudinal studies $(n=10)$, enrolling 12375 subjects, baseline TT level was significantly lower among patients with incident overall- and CV-related mortality, in comparison with controls (Fig. 6A and B). Conversely, we did not observe any difference in baseline TT levels between case and controls for incident CVD (Fig. 6C). Similarly, baseline $\mathrm{E}_{2}$ levels were not different in patients who have found to have CVD at follow-up (Fig. 6D). No analyses for the overall and CV mortality were performed for $E_{2}$, due to insufficient data.

\section{Clinical trials}

The six RCTs available enrolled 258 patients with CHD, with a mean follow-up of 23 weeks. Although all of these trials enrolled only CHD patients, they differ in basal TT levels (Tables 3 and 4). In addition, TRT was administered in different formulations and doses
(Table 3). Combining the results of those trials, TRT was positively associated with a significant increase in treadmill test duration and time to $1 \mathrm{~mm}$ ST segment depression (Fig. 7A and B). Similar results were observed when studies evaluating an acute testosterone effect (with i.v. testosterone or placebo administration) were excluded from the analysis (mean difference in reaching $1 \mathrm{~mm}$ ST depression $=98.592 \quad(20.027-$ 177.157) s; $P<0.014)$.

\section{Discussion}

This is the first study that systematically and comprehensively explores available data on the association between testosterone (and related sex steroids) and CVD in men. Our results show that both low testosterone and high $E_{2}$ levels are independently associated with overall $\mathrm{CV}$ and CHD in cross-sectional surveys. In addition, in longitudinal observational studies, while low testosterone predicts overall and CV mortality, no association between both testosterone and $\mathrm{E}_{2}$ and $\mathrm{CV}$ incidence has been found. Finally, no relationship between DHEAS and CVD has been observed.

The role of androgens in the pathogenesis of CVD is also a matter of debate. Phillips et al. (24) first reported an inverse relationship between free testosterone (FT) levels and the degree of $\mathrm{CAD}$ in a group of subjects undergoing coronary angiography. Similar results were confirmed thereafter by Zhao et al. (48).

Table 4 Outcome variables in individual randomized controlled studies included in the meta-analysis. All data are reported as mean \pm s.D.

\begin{tabular}{|c|c|c|c|c|c|c|c|c|}
\hline References & $\begin{array}{l}\text { No. of } \\
\text { patients } \\
\text { (ID/C) }\end{array}$ & $\begin{array}{l}\text { Trial } \\
\text { duration } \\
\text { (weeks) }\end{array}$ & $\begin{array}{l}\text { Age } \\
\text { (years) }\end{array}$ & $\begin{array}{l}\text { TT } \\
\text { baseline } \\
\text { (nmol/l) }\end{array}$ & $\begin{array}{l}\text { DM } \\
\text { baseline } \\
(\%)\end{array}$ & $\begin{array}{l}\text { MI } \\
\text { baseline } \\
(\%)\end{array}$ & $\begin{array}{l}\text { Exercise } \\
\text { duration } \\
\text { endpoint } \\
\text { (s ID/C) }\end{array}$ & $\begin{array}{l}\text { Time to } 1 \mathrm{~mm} \mathrm{ST} \\
\text { depression endpoint } \\
\text { (s ID/C) }\end{array}$ \\
\hline (76) & $7 / 7$ & - & 58.0 & NA & 7.1 & 35.7 & $631.0 \pm 180.0 / 541.0 \pm 204.0$ & $579.0 \pm 204.0 / 471.0 \pm 210.0$ \\
\hline (77) & $14 / 14$ & - & 57.0 & 5.3 & 21.4 & 50.0 & NA & $364.0 \pm 149.7 / 298.0 \pm 127.2$ \\
\hline (78) & $22 / 24$ & 14 & 62.0 & 12.9 & 15.3 & 10.9 & NA & $361.0 \pm 103.2 / 292.0 \pm 117.6$ \\
\hline (79) & $34 / 34$ & - & 69.1 & NA & NA & 32.0 & NA & $294.0 \pm 132.0 / 288.0 \pm 132.0$ \\
\hline (80) & $10 / 10$ & 4 & 60.8 & 4.2 & 50.0 & 30.0 & NA & $399.0 \pm 84.0 / 352.0 \pm 150.0$ \\
\hline (81) & $7 / 6$ & 52 & 64.8 & 9.9 & 23.1 & 30.8 & $463.6 \pm 46.2 / 363.3 \pm 143.5$ & $449.0 \pm 67.5 / 262.7 \pm 110.3$ \\
\hline
\end{tabular}

ID/C, investigational drug/comparator; TT, total testosterone; DM, diabetes mellitus; MI, myocardial infarction; NA, not available; s, second.

${ }^{a}$ Supra-physiologic $(6 \times$ baseline $)$ serum testosterone level. 
Conversely, conflicting results have been reported in cross-sectional studies, comparing subjects with CHD to healthy controls $(1,51,83)$. Our meta-analysis shows that patients with CVD have, on average, lower testosterone level than healthy controls. Furthermore,
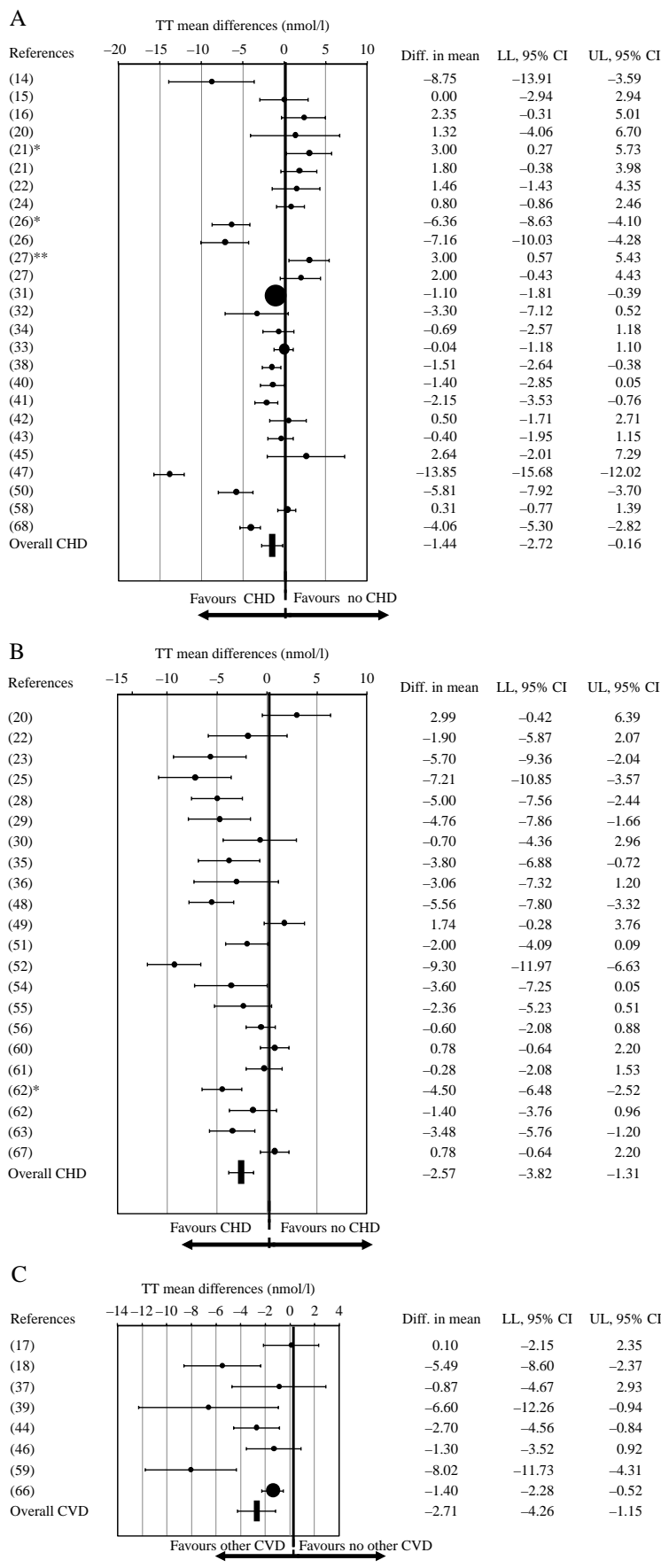

Figure 2 Weighted differences (with $95 \% \mathrm{Cl}$ ) of mean total testosterone (TT) between non-angiographically documented (A), angiographically documented (B) coronary heart diseases (CHD) or other types of cardiovascular diseases (CVD; C) and controls from cross-sectional studies. *Acute myocardial infarction. ${ }^{* *}$ Normotensive group.
Table 5 Weighted differences (with $95 \% \mathrm{Cl}$ ) of mean SHBG and DHEAS between patients with cardiovascular diseases and controls from cross-sectional studies.

\begin{tabular}{|c|c|c|c|c|c|c|c|c|}
\hline \multirow[b]{2}{*}{$\begin{array}{l}\text { Refer- } \\
\text { ences }\end{array}$} & \multicolumn{3}{|c|}{ SHBG (nmol/l) } & & \multicolumn{3}{|c|}{ DHEAS $(\mu \mathrm{mol} / \mathrm{l})$} & \multirow[b]{2}{*}{$\boldsymbol{P}$} \\
\hline & $\begin{array}{l}\text { Differ- } \\
\text { ences in } \\
\text { means }\end{array}$ & $\begin{array}{l}\text { LL } \\
(95 \% \\
\mathrm{Cl})\end{array}$ & $\begin{array}{l}\text { UL } \\
(95 \% \\
\text { Cl) }\end{array}$ & $\boldsymbol{P}$ & $\begin{array}{l}\text { Differ- } \\
\text { ences in } \\
\text { means }\end{array}$ & $\begin{array}{l}\mathrm{LL} \\
(95 \% \\
\mathrm{Cl})\end{array}$ & $\begin{array}{c}\text { UL } \\
(95 \% \\
\mathrm{Cl})\end{array}$ & \\
\hline (28) & -3.20 & -10.96 & 4.56 & 0.42 & - & - & - & - \\
\hline (30) & 2.60 & -4.93 & 10.13 & 0.50 & - & - & - & - \\
\hline (33) & 2.30 & -1.17 & 5.77 & 0.19 & - & - & - & - \\
\hline (35) & 1.62 & -4.96 & 8.20 & 0.63 & - & - & - & - \\
\hline (36) & -1.20 & -5.93 & 3.53 & 0.62 & -1.74 & -3.16 & -0.32 & 0.02 \\
\hline (38) & -2.58 & -5.60 & 0.44 & 0.09 & - & - & - & - \\
\hline (40) & 1.20 & -2.77 & 5.17 & 0.55 & -0.10 & -1.12 & 0.92 & 0.85 \\
\hline (42) & 3.60 & -3.03 & 10.23 & 0.29 & 1.10 & -0.13 & 2.33 & 0.08 \\
\hline (43) & -3.70 & -9.39 & 1.99 & 0.20 & - & - & - & - \\
\hline (45) & 1.10 & -8.69 & 10.89 & 0.83 & - & - & - & - \\
\hline (46) & -4.90 & -10.98 & 1.18 & 0.11 & -1.40 & -2.28 & -0.52 & 0.00 \\
\hline (51) & 2.05 & -3.47 & 7.57 & 0.47 & 0.00 & -0.96 & 0.96 & 1.00 \\
\hline (52) & 3.00 & -2.37 & 8.37 & 0.27 & - & - & - & - \\
\hline (54) & 3.70 & -2.54 & 9.94 & 0.25 & -0.62 & -1.84 & 0.61 & 0.32 \\
\hline (55) & 4.70 & -0.40 & 9.80 & 0.07 & 0.66 & -0.39 & 1.72 & 0.22 \\
\hline (56) & -1.71 & -5.52 & 2.10 & 0.38 & -0.70 & -1.68 & 0.28 & 0.16 \\
\hline (57) & - & - & - & - & 0.11 & -0.22 & 0.44 & 0.52 \\
\hline (58) & -2.74 & -9.04 & 3.56 & 0.39 & - & - & - & - \\
\hline$(62)^{a}$ & -4.70 & -8.86 & -0.54 & 0.03 & - & - & - & - \\
\hline (62) & 3.40 & -1.41 & 8.21 & 0.17 & - & - & - & - \\
\hline (64) & -14.50 & -21.25 & -7.75 & 0.00 & -0.14 & -0.65 & 0.38 & 0.61 \\
\hline (66) & 1.50 & -0.86 & 3.86 & 0.21 & 1.50 & -0.86 & 3.86 & 0.21 \\
\hline (67) & - & - & - & - & 0.12 & -0.29 & 0.53 & 0.57 \\
\hline (68) & -78.52 & -95.68 & -61.36 & 0.00 & -1.22 & -1.56 & -0.88 & 0.00 \\
\hline Overall & -1.67 & -4.29 & 0.95 & 0.21 & -0.32 & -0.76 & 0.13 & 0.16 \\
\hline
\end{tabular}

LL, lower limit; UL, upper limit.

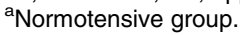

the presence of several associated morbidities, such as diabetes, obesity, and hypertension, are associated with increased testosterone differences between cases and controls, confirming numerous clinical observations. All of these morbidities were previously found to be associated with male hypogonadism $(1,84-86)$. It has been shown in previous meta-analyses $(87,88)$ that diabetes, in particular type 2 diabetes mellitus (T2DM), is a clinical condition which is often comorbid with a reduction in circulating testosterone in males, most probably from mixed (central and peripheral) hypogonadism. Accordingly, the recently updated Endocrine Society Guidelines suggests a systematic investigation for possible hypogonadism in diabetic patients (89). The association between obesity and hypogonadism is also well documented (84-86). The European Male Aging study, a large population-based study involving more than 3000 subjects enrolled in eight different European centers, confirms a stepwise reduction in testosterone levels as a function of obesity class and number of associated morbidities, without a concomitant LH rise (90). Conversely, the relationship between testosterone levels and hypertension is more controversial (91). In particular, while some studies have shown reduced androgen levels in subjects with essential hypertension $(92,93)$, others did not confirm these results (21). We previously demonstrated that only pulse pressure (i.e. the arithmetic difference 
A

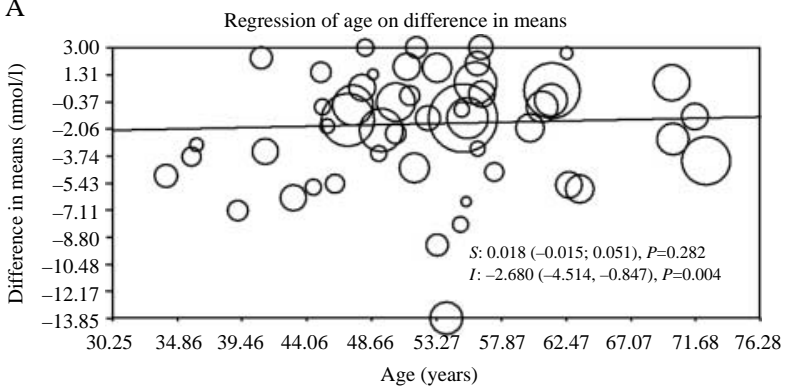

B

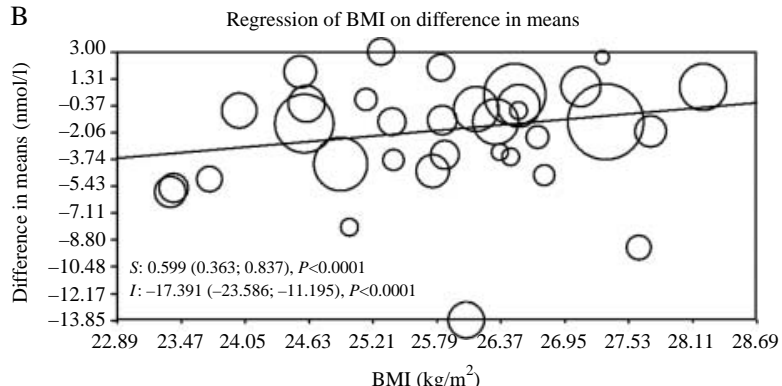

$\mathrm{C}$

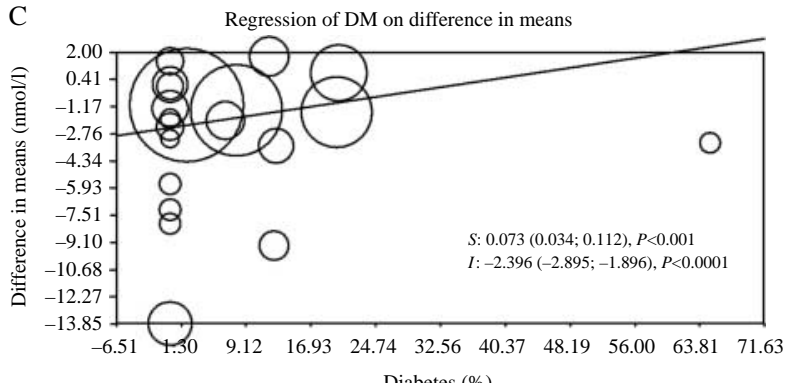

D

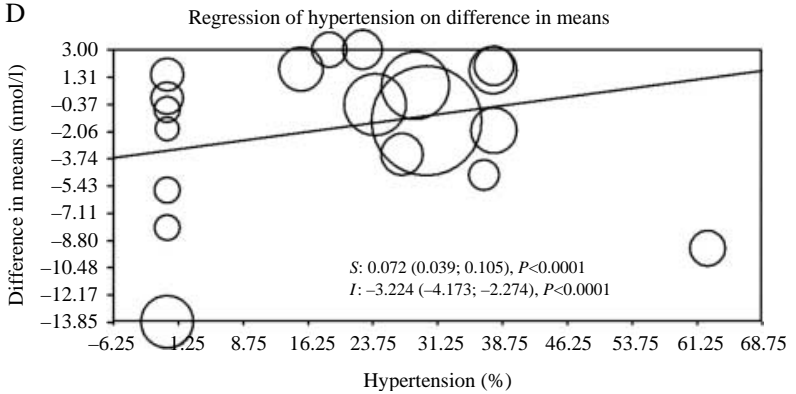

Figure 3 Influence of age (A) and body mass index (BMl; B), diabetes mellitus (DM; C), and hypertension (D) on total testosterone weighted mean differences between patients with cardiovascular diseases and controls.

between systolic and diastolic blood pressure), but not systolic or diastolic blood pressure, is androgen dependent (94). No information on pulse pressure was available in the studies included in this study. It is important to note that when testosterone levels were introduced as a covariate in a logistic model, together with the aforementioned morbidities, they retain an independent, negative association with CVD. In longitudinal studies, baseline low testosterone predicts overall and CV-related mortality but not incident CVD.
Taken together, these results suggest that low testosterone may be considered as a marker of poor general health status, negatively affecting prognosis, rather than a specific CV risk factor $(11,84-86,95)$. Low testosterone level has also been associated with an increased mortality in patients affected by nonCVD, such as hypopituitarism (96), Klinefelter's syndrome (97), and mental retardation (98), as well as in specific populations, such as Veterans (99).

Conversely, longitudinal observational studies in prostate cancer patients show that androgen ablation is associated with an increased incidence of CVD (100-104). Although this suggests that suppressed testosterone might have a causal role in CV frailty, the castrate testosterone levels resulting from testosterone ablation may not really be compared to the slightly decreased testosterone levels observed in men with CVD. In addition, the association between low testosterone and forthcoming CVD was obtained in a rather selective population sample, such as those with prostate cancer. Studies performed in community-dwelling males have provided conflicting results (see for review reference (1)). Some authors did not report any association between testosterone levels and $\mathrm{CV}$ morbidity, after adjusting for confounders (33, 70, 71, 105-108). Conversely, data from the Health In Men Study (74) suggested a strong relationship between low to normal levels of TT and incidence of cerebrovascular events, whereas overt low testosterone levels $(\mathrm{TT}<8 \mathrm{nmol} / \mathrm{l})$ were not significantly related to incidence of transitory ischemic attack (TIA) and stroke in elderly men.

Available data show that testosterone enhances myocardial function through direct and indirect effect on myocardiocytes $(109,110)$; it is therefore possible that hypogonadism leads to an increased functional damage following the onset of coronary artery disease.

In order to verify the causal relationship between hypogonadism and CVD, data from interventional studies (i.e. RCTs) are helpful. Isidori et al. (111) reported that TRT in middle-aged men is able to reduce fat mass and total cholesterol. Similarly, Whitsel et al. (112), in a meta-analysis on the effects of i.m. TRT in hypogonadal men, showed a small dose-dependent decrease in total cholesterol and LDL- and HDLcholesterol. Very few RCTs have evaluated the impact of TRT in patients with metabolic syndrome (MetS) and T2DM. In patients with MetS, TRT was associated with a significant reduction in fasting plasma glucose, HOMA index, triglycerides, and waist circumference as well as with an increase in HDL-cholesterol (113). Similar results were observed when T2DM was considered. In particular, TRT was associated with a significant reduction in fasting plasma glucose, $\mathrm{HbA1c}$, fat mass, and triglycerides (88).

A previous meta-analysis on 30 placebo-controlled studies, evaluating the effect of TRT on CV events, showed TRT safety, because it was not associated with an increased risk of CVD (114). Similar results were 
A

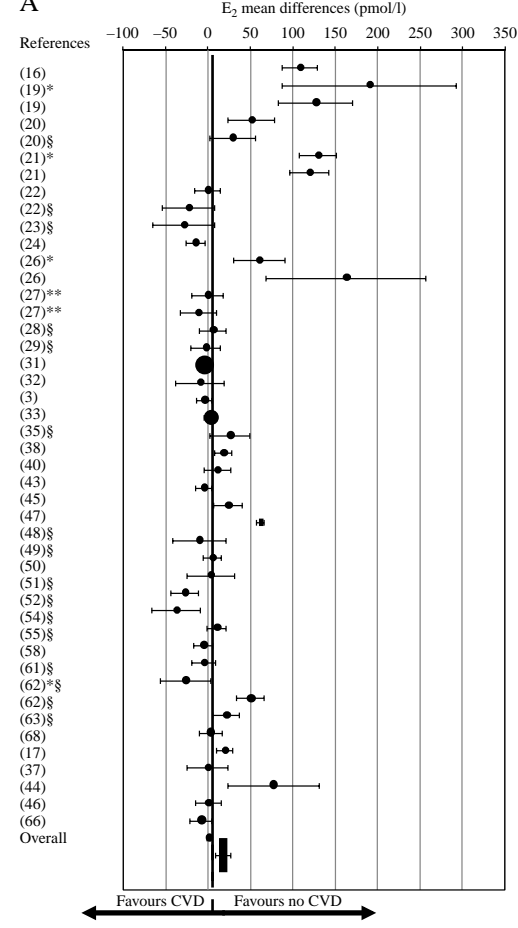

B

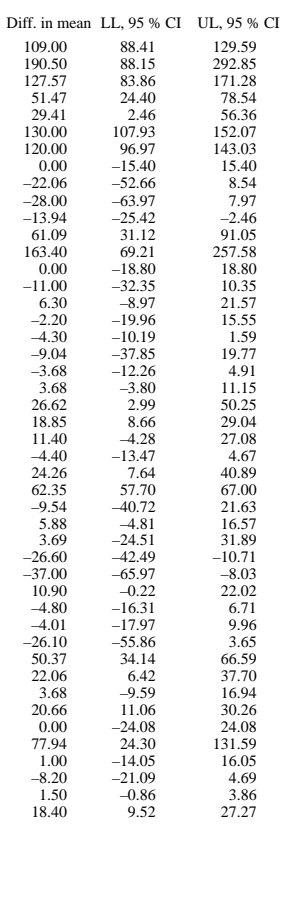

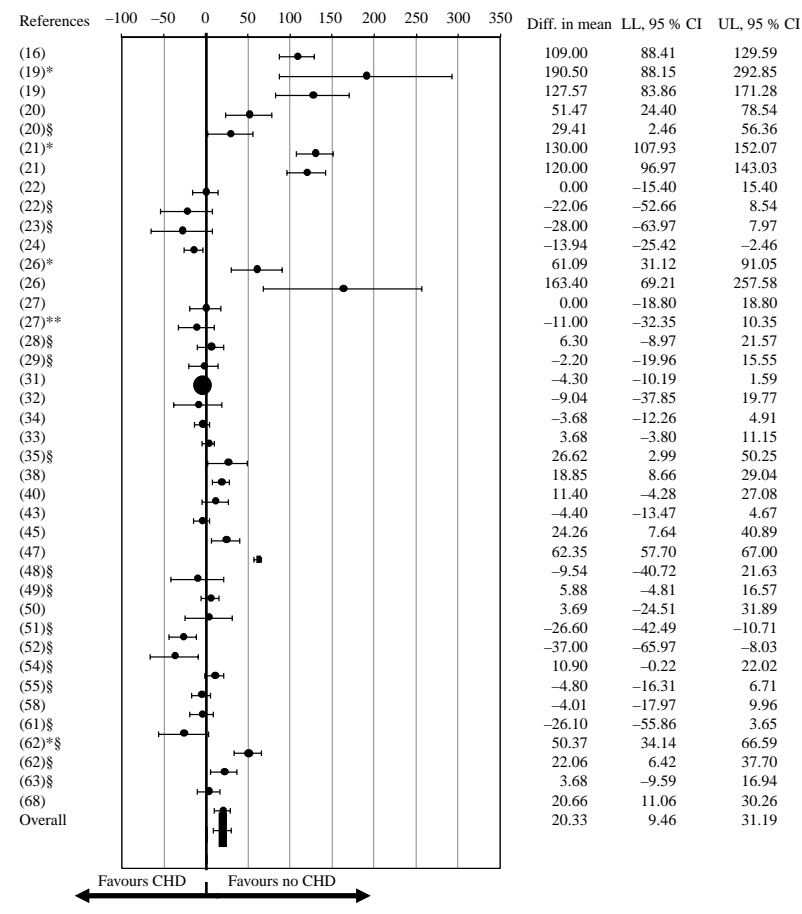

Figure 4 Weighted differences (with $95 \% \mathrm{Cl}$ ) of mean total $17-\beta$ estradiol $\left(E_{2}\right)$ between cardiovascular disease (CVD; $A$ ) or coronary heart disease (CHD; B) and controls from cross-sectional studies. *Acute myocardial infarction. ${ }^{* \star}$ Normotensive group. ${ }^{\S} \mathrm{CHD}$ angiographically documented.

more recently reported by Fernández-Balsells et al. (115) who meta-analyzed 51 placebo-controlled studies with follow-up ranging from 3 months up to 3 years. Interestingly, we now report that TRT is effective in men with chronic stable angina, as they had greater angina-free exercise tolerance than placebo-treated controls. The possible beneficial effect of chronic TRT on CV risk needs to be better elucidated through largescale, long-term, placebo-controlled studies.

Data from the Health in Men Study, a populationbased study of 3616 men aged 70-88 years, have documented that low free testosterone independently predicted frailty (HR 1.22 (1.05-1.42)) (116). Recent RCT studies on the effect of transdermal testosterone on two groups of more than 200 hypogonadal (TT below $12 \mathrm{nmol} / \mathrm{l}$ ) elderly men with frailty indicated that TRT prevents age-associated loss of lower limb muscle strength, while improving body composition, quality of life, and physical function $(117,118)$. These two RCTs were not included in the present meta-analysis because they did not fulfill our inclusion criteria. In the Testosterone in Older Men with Mobility Limitation trial (117), employing in some patients a high testosterone dose $(100 \mathrm{mg}$ of a $1 \%$ gel) in order to obtain a serum testosterone level in the target range, the treated frail elderly men reported a high rate of $\mathrm{CV}$ adverse events, which induced a premature termination of the study. The same authors recognized that the generalizability of these data about the safety of TRT are limited by several factors, including that $\mathrm{CV}$ events were i) observed in a population characterized by a high prevalence of chronic disease, ii) not a planned primary or secondary outcome, and iii) the number of adverse events was relatively small (23 vs $5 \%$, respectively, for treatment and placebo arms).

While low testosterone level could contribute to the pathogenesis of CVD, the reverse is also possible. It can be speculated that CVD-associated hypogonadism is an adaptive mechanism. In fact, we cannot exclude the possibility that low testosterone, as observed in several chronic diseases, has a protective role by turning off testosterone-dependent functions (such as reproduction and physical labor) that are not desirable when the physical condition is ailing. A recent longitudinal observational study confirms that hypogonadism is a $\mathrm{CV}$ risk marker in lean subjects. However, in those with higher BMI, hypogonadism is associated with a lower CV risk, suggesting that testosterone reduction induced by adiposity could have a beneficial effect (95). Hence, the suppression of testosterone in obesity could represent a protective mechanism.

In our meta-analysis, higher $\mathrm{E}_{2}$ level was associated with prevalent CVD in cross-sectional studies, but it was not a predictor of incident CVD in longitudinal studies. This apparent discrepancy could be accounted for by several factors. If high $\mathrm{E}_{2}$ is an indicator of poor health 
A
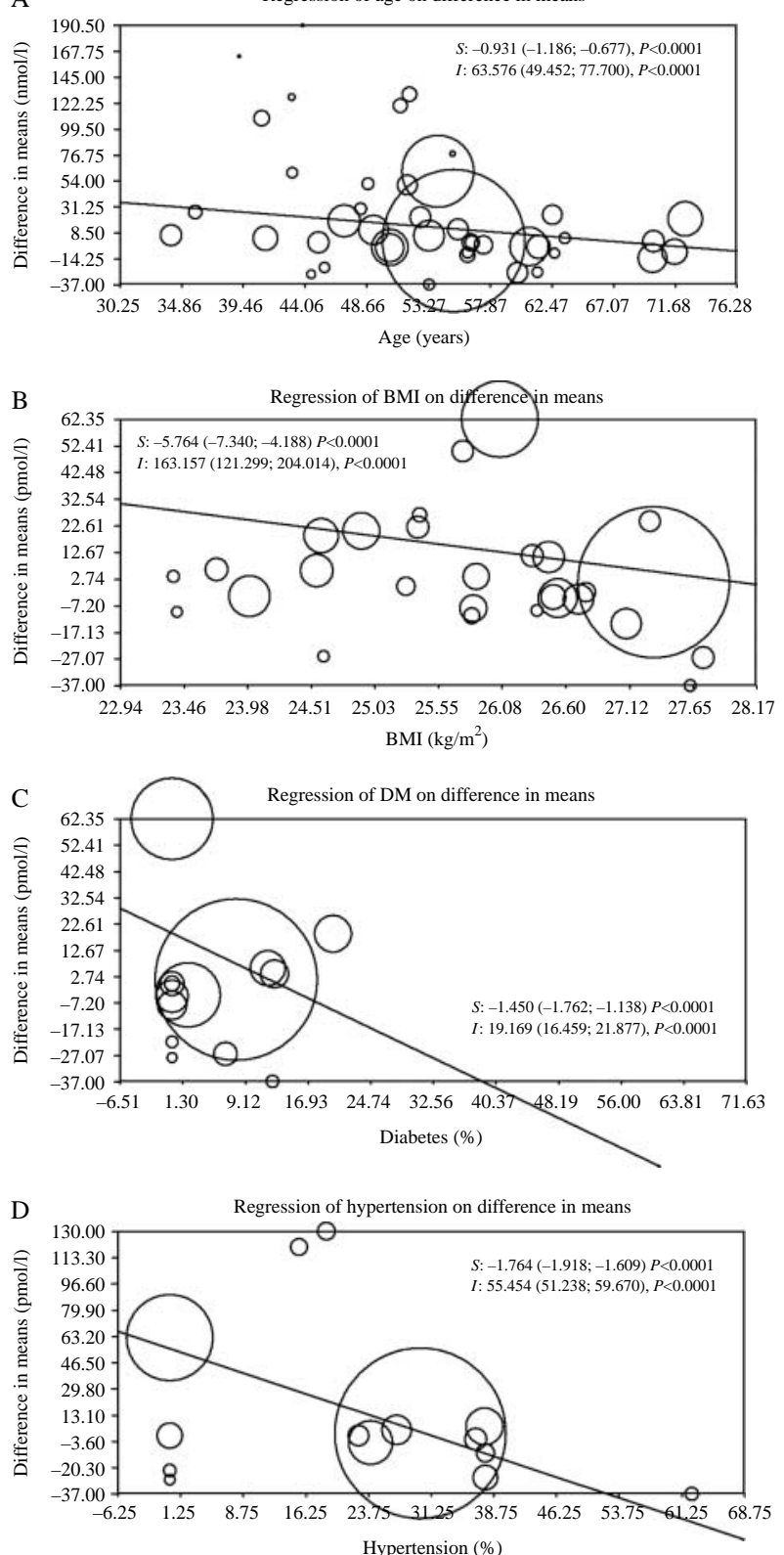

Figure 5 Influence of age (A) and body mass index (BMI; B), diabetes mellitus (DM; C), and hypertension (D) on total 17- $\beta$ estradiol weighted mean differences between patients with cardiovascular disease and controls.

status $(33,106,107,119-124)$ or obesity $(84-86$, $125,126)$, its higher level could be the consequence, rather than the cause, of CVD. However, it is also possible that the limited size and number of longitudinal cohort studies prevented the detection of the effect of $\mathrm{E}_{2}$ on incident $\mathrm{CVD}$.

DHEA and its sulfate (DHEAS) are steroids abundantly present in peripheral circulation, without a clear physiological role, apart from being precursors of bioactive androgens. However, they have been implicated in a broad range of biological abnormalities including obesity, diabetes, osteoporosis, cancer, and mental disorders (127). In addition, there is a widespread, non-supervised use of DHEA as a dietary supplement for elderly people in the hope of a fountain of youth. However, the results of several small DHEA supplementation studies are rather inconclusive, if not negative $(128,129)$. Epidemiological studies demonstrate that the association between low DHEAS and all-cause or CVD mortality is, at least, conflicting

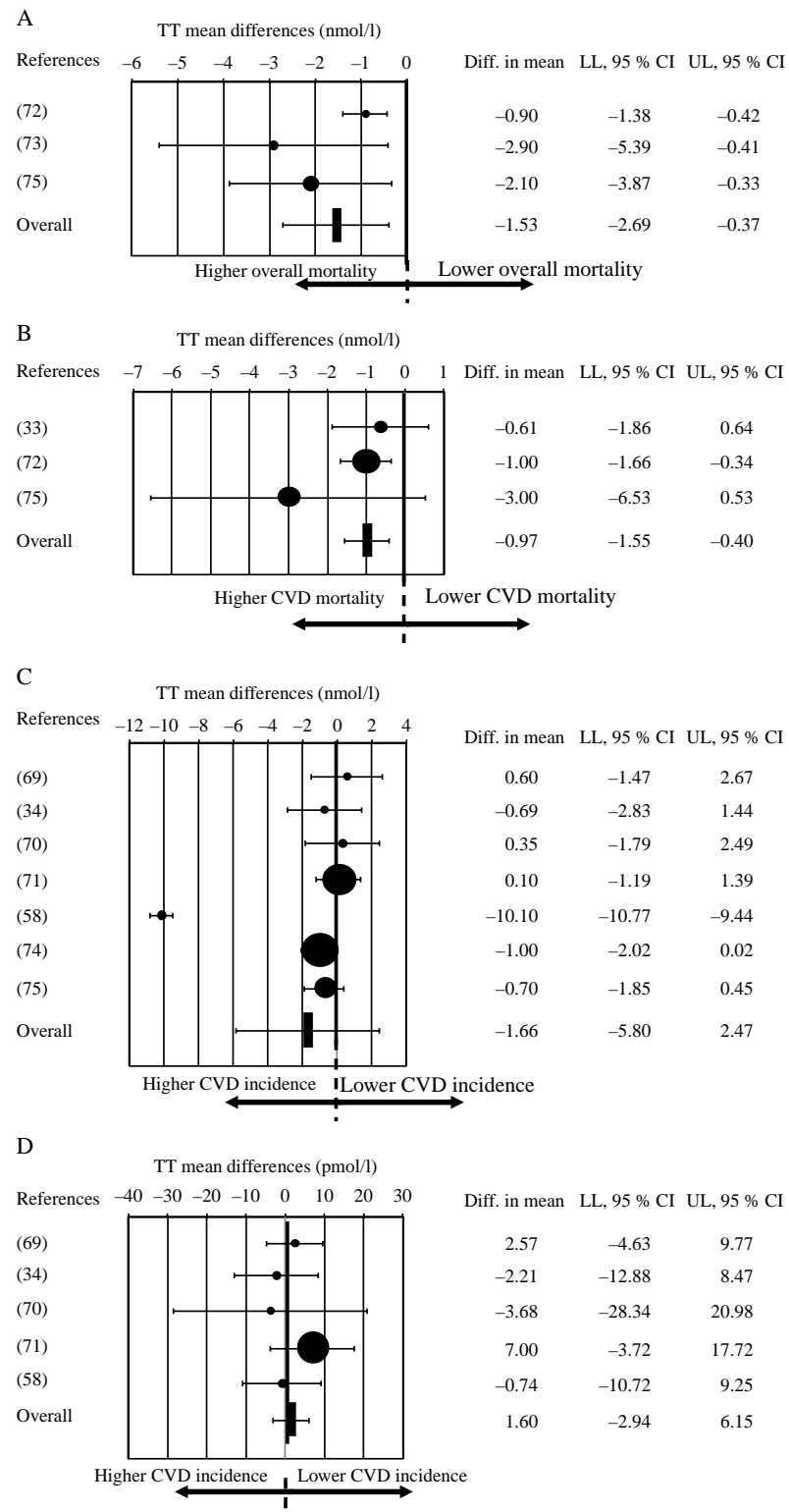

Figure 6 Baseline weighted differences (with $95 \% \mathrm{Cl}$ ) of mean total testosterone (TT) between patients with incident overall (A) and cardiovascular disease (CVD) mortality (B) or incident CVD (C) and controls from longitudinal studies. D) Baseline weighted differences (with $95 \% \mathrm{Cl}$ ) of mean $17-\beta$ estradiol $\left(E_{2}\right)$ between patients with incident $\mathrm{CVD}$ and controls from longitudinal studies. 


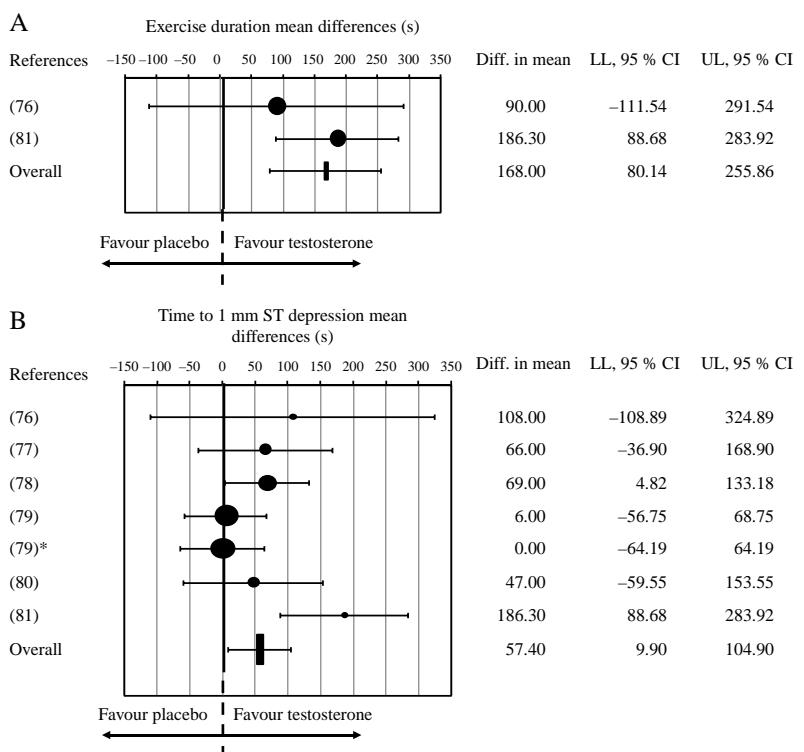

Figure 7 Weighted differences (with 95\% Cl) of mean treadmill test duration $(A)$ and time to $1 \mathrm{~mm}$ ST segment depression (B) during treadmill test at endpoint across randomized controlled trials. ${ }^{*}$ Supra-physiologic $(6 \times$ baseline) serum testosterone level.

(130-135). Our study found no significant relationship between DHEAS levels and CVD.

Several limitations should be recognized. Potential selection bias and confounding factors may exist. Several longitudinal studies evaluating the incidence of CVD or CVD mortality were not included in the present meta-analysis, since they do not report continuous hormone values. Data on $\mathrm{E}_{2}$ should be considered with caution since the assays used in these publications is missing. The number and the duration of RCTs as well as the number of the patients enrolled are very limited. However, it should be important to emphasize that we considered only studies evaluating the effect of TRT on CV parameters derived from treadmill test in men with chronic stable angina. Further prospective investigations on TRT in CVD and CHD patients are advisable.

\section{Conclusions}

This meta-analysis of the relationship between testosterone and CVD, risks and consequences, reinforces many other studies but unifies several of the concepts previously published separately. Low testosterone levels have been shown to correlate significantly with $\mathrm{CV}$ risk factors but also with the incidence of CHD events, and indeed, with the incidence of CVD events in general. This also correlates with the ultimate risk of mortality itself. This is very important as the review began by reminding us that death due to CVD is the most common cause of mortality in men. One interesting finding was that the increase in CVD was associated with medical co-factors, especially obesity, diabetes, and hypertension, and not a function of age per se. These findings were also accompanied by a higher $\mathrm{E}_{2}$ level, which may be more a result of the medical conditions and risks, rather than a cause. It is therefore very important that clinicians look for hypogonadism in men with CV risk factors and disease and conversely look for $\mathrm{CV}$ comorbidities when hypogonadism is found. The encouraging news is that early studies have shown that treatment of low testosterone states may moderate many of the medical co-factors and thus may decrease CV risks (136). This has to be proven with much larger numbers followed over a longer period of time so that we can see whether treatment of hypogonadism may actually decrease CV events, data that we do not have at this point in time. This conclusion leads to an unsolved dilemma: is low testosterone level in CVD a positive consequence of the body trying to decrease unnecessary energy by reducing reproductive expenditure in order to survive, or does it represent a pathophysiologic factor in the same illness? In the first scenario, testosterone supplementation may not be advisable, whereas in the second scenario it would be recommended. Present available data are not sufficient to sort out the beneficial or harmful effects of TRT on CV morbidity and mortality.

\section{Declaration of interest}

The authors declare that there is no conflict of interest that could be perceived as prejudicing the impartiality of the research reported.

\section{Funding}

Part of the study was supported by PRIN (Programmi di ricerca di Rilevante Interesse Nazionale) funds by the Italian Minister of University, Research and Instruction (prot number:2009WLN XNT_002).

\section{References}

1 Corona G, Rastrelli G, Vignozzi L, Mannucci E \& Maggi M. Testosterone, cardiovascular disease and the metabolic syndrome. Best Practice \& Research. Clinical Endocrinology \& Metabolism 201125 337-353. (doi:10.1016/j.beem.2010.07. 002)

2 Atlas of health in Europe, 2nd edition 2008. WHO Library Cataloguing-in-Publication 2008.

3 Courtenay WH \& Keeling RP. Men, gender, and health: toward an interdisciplinary approach. Journal of American College Health 200048 243-246. (doi:10.1080/07448480009596265)

4 Stramba-Badiale M, Fox KM, Priori SG, Collins P, Daly C, Graham I, Jonsson B, Schenck-Gustafsson K \& Tendera M. Cardiovascular diseases in women: a statement from the policy conference of the European Society of Cardiology. European Heart Journal 200627 994-1005. (doi:10.1093/eurheartj/ehi819)

5 Wingard DL, Suarez L \& Barrett-Connor E. The sex differential in mortality from all causes and ischemic heart disease. American Journal of Epidemiology 1983117 165-172.

6 Osler W. Lectures on Angina Pectoris and Allied States. New York, NY: D Appleton \& Co, 1897. 
7 Friedman M \& Rosenman RH. Association of specific overt behavior pattern with blood and cardiovascular findings: blood cholesterol level, blood clotting time, incidence of arcus senilis, and clinical coronary artery disease. Journal of the American Medical Association $19591691286-1296$.

8 Haynes SG, Levine S, Scotch N, Feinleib M \& Kannel WB. The relationship of psychosocial factors to coronary heart disease in the Framingham Study, 1: methods and risk factors. Journal of the American Medical Association 1978107 362-383.

9 Bem SL. The measurement of psychological androgyny. Journal of Consulting and Clinical Psychology 197442 155-162. (doi:10. 1037/h0036215)

10 Tudiver F \& Talbot Y. Why don't men seek help? Family physicians' perspectives on help-seeking behaviour in men Journal of Family Practice $1999 \mathbf{4 8}$ 47-52.

11 Guay A, Seftel AD \& Traish A. Hypogonadism in men with erectile dysfunction may be related to a host of chronic illnesses. International Journal of Impotence Research 201022 9-19. (doi:10.1038/ijir.2009.46)

12 Buvat J, Maggi M, Gooren L, Guay AT, Kaufman J, Morgentaler A, Schulman C, Tan HM, Torres LO, Yassin A \& Zitzmann M. Endocrine aspects of male sexual dysfunctions. Journal of Sexual Medicine 20107 1627-1656. (doi:10.1111/j.1743-6109.2010. 01780.x)

13 Ruige JB, Mahmoud AM, De Bacquer D \& Kaufman JM. Endogenous testosterone and cardiovascular disease in healthy men: a meta-analysis. Heart 201097 870-875. (doi:10.1136/ hrt.2010.210757)

14 Poggi UL, Argüelles AE, Rosner J, de Laborde NP, Cassini JH \& Volmer MC. Plasma testosterone and serum lipids in male survivors of myocardial infarction. Journal of Steroid Biochemistry 19767 229-231. (doi:10.1016/0022-4731(76)90206-5)

15 Halim MM, Meyrick G, Jeans WD, Murphy D \& Burton JL. Myocardial infarction, androgen and the skin. British Journal of Dermatology 197898 63-68. (doi:10.1111/j.1365-2133.1978. tb07334.x)

16 Entrican JH, Beach C, Carroll D, Klopper A, Mackie M \& Douglas AS. Raised plasma oestradiol and oestrone levels in young survivors of myocardial infarction. Lancet $1978 \mathbf{2}$ 487-490. (doi:10.1016/S0140-6736(78)92215-8)

17 Taggart H, Sheridan B \& Stout RW. Sex hormone levels in younger male stroke survivors. Atherosclerosis $1980 \quad \mathbf{3 5}$ 123-125. (doi:10.1016/0021-9150(80)90034-9)

18 Foresta C, Ruzza G, Mioni R, Dalla Costa F \& Mastrogiacomo I. Male hypogonadism in aorto-iliac arteriopathies. Archives of Andrology 19829 297-301. (doi:10.3109/0148501820899 0254)

19 Klaiber EL, Broverman DM, Haffajee CI, Hochman JS, Sacks GM \& Dalen JE. Serum estrogen levels in men with acute myocardial infarction. American Journal of Medicine $1982 \quad 73 \quad 872-881$. (doi:10.1016/0002-9343(82)90779-3)

20 Luria MH, Johnson MW, Pego R, Seuc CA, Manubens SJ, Wieland MR \& Wieland RG. Relationship between sex hormones, myocardial infarction, and occlusive coronary disease. Archives of Internal Medicine 1982142 42-44. (doi:10.1001/archinte.142. 1.42)

21 Labropoulos B, Velonakis E, Oekonomakos P, Laskaris J \& Katsimades D. Serum sex hormones in patients with coronary disease and their relationship to known factors causing atherosclerosis. Cardiology 198269 98-103. (doi:10.1159/ 000173490)

22 Zumoff B, Troxler RG, O’Connor J, Rosenfeld RS, Kream J, Levin J, Hickman JR, Sloan AM, Walker W, Cook RL \& Fukushima DK. Abnormal hormone levels in men with coronary artery disease. Arteriosclerosis 19822 58-67. (doi:10.1161/01.ATV.2.1.58)

23 Barth JD, Jansen H, Hugenholtz PG \& Birkenhäger JC. Postheparin lipases, lipids and related hormones in men undergoing coronary arteriography to assess atherosclerosis. Atherosclerosis 198348 235-241. (doi:10.1016/0021-9150(83)90041-2)

24 Phillips GB, Castelli WP, Abbott RD \& McNamara PM. Association of hyperestrogenemia and coronary heart disease in men in the Framingham cohort. American Journal of Medicine 1983 74 863-869. (doi:10.1016/0002-9343(83) 91078-1)

25 Hromadová M, Hácik T \& Riecanský I. Concentration of lipid, apoprotein-B and testosterone in patients with coronarographic findings. Klinische Wochenschrift 198563 1071-1074. (doi:10. 1007/BF01739675)

26 Aksüt SV, Aksüt G, Karamehmetoglu A \& Oram E. The determination of serum estradiol, testosterone and progesterone in acute myocardial infarction. Japanese Heart Journal 198627 825-837. (doi:10.1536/ihj.27.825)

27 Franzén J \& Fex G. Low serum apolipoprotein A-I in acute myocardial infarction survivors with normal HDL cholesterol. Atherosclerosis 198659 37-42. (doi:10.1016/0021-9150(86) 90030-4)

28 Sewdarsen M, Jialal I, Vythilingum S \& Desai R. Sex hormone levels in young Indian patients with myocardial infarction. Arteriosclerosis $1986 \quad 6$ 418-421. (doi:10.1161/01.ATV.6.4. 418)

29 Chute CG, Baron JA, Plymate SR, Kiel DP, Pavia AT, Lozner EC, O'Keefe T \& MacDonald GJ. Sex hormones and coronary artery disease. American Journal of Medicine 198783 853-859. (doi:10. 1016/0002-9343(87)90642-5)

30 Hämäläinen E, Tikkanen $H$, Härkönen $M$, Näveri $H$ \& Adlercreutz H. Serum lipoproteins, sex hormones and sex hormone binding globulin in middle-aged men of different physical fitness and risk of coronary heart disease. Atherosclerosis 198767 155-162. (doi:10.1016/0021-9150(87)90275-9)

31 Lichtenstein MJ, Yarnell JW, Elwood PC, Beswick AD, Sweetnam PM, Marks V, Teale D \& Riad-Fahmy D. Sex hormones, insulin, lipids, and prevalent ischemic heart disease. American Journal of Epidemiology 1987126 647-657.

32 Small M, MacRury S, Beastall GH \& MacCuish AC. Oestradiol levels in diabetic men with and without a previous myocardial infarction. Quarterly Journal of Medicine 198764 617-623.

33 Barrett-Connor E \& Khaw KT. Endogenous sex hormones and cardiovascular disease in men. A prospective population-based study. Circulation 198878 539-545. (doi:10.1161/01.CIR.78.3.539)

34 Phillips GB, Yano K \& Stemmermann GN. Serum sex hormone levels and myocardial infarction in the Honolulu Heart Program. Pitfalls in prospective studies on sex hormones. Journal of Clinical Epidemiology 1988 41 1151-1156. (doi:10.1016/0895-4356 (88)90018-2)

35 Sewdarsen M, Jialal I \& Naidu RK. The low plasma testosterone levels of young Indian infarct survivors are not due to a primary testicular defect. Postgraduate Medical Journal 198864 264-266. (doi:10.1136/pgmj.64.750.264)

36 Słowínska-Srzednicka J, Zgliczyński S, Ciświcka-Sznajderman M, Srzednicki M, Soszyński P, Biernacka M, Woroszyłska M, Ruzyłło W \& Sadowski Z. Decreased plasma dehydroepiandrosterone sulfate and dihydrotestosterone concentrations in young men after myocardial infarction. Atherosclerosis $1989 \mathbf{7 9}$ 197-203. (doi:10.1016/0021-9150(89)90124-X)

37 Elwan O, Abdallah M, Issa I, Taher Y \& el-Tamawy M. Hormonal changes in cerebral infarction in the young and elderly. Journal of Neurological Sciences 199098 235-243. (doi:10.1016/0022510X(90)90264-N)

38 Sewdarsen M, Vythilingum S, Jialal I, Desai RK \& Becker P. Abnormalities in sex hormones are a risk factor for premature manifestation of coronary artery disease in South African Indian men. Atherosclerosis 199083 111-117. (doi:10.1016/00219150(90)90156-D)

39 Dash RJ, Sethi BK, Nalini K \& Singh S. Circulating testosterone in pure motor stroke. Functional Neurology 19916 29-34.

40 Hauner H, Stangl K, Burger K, Busch U, Blömer H \& Pfeiffer EF. Sex hormone concentrations in men with angiographically assessed coronary artery disease - relationship to obesity and body fat distribution. Klinische Wochenschrift $199169664-668$. (doi:10.1007/BF01649428)

41 Rice T, Sprecher DL, Borecki IB, Mitchell LE, Laskarzewski PM \& Rao DC. Cincinnati myocardial infarction and hormone family 
study: family resemblance for testosterone in random and MI families. American Journal of Medical Genetics 199347 542-549. (doi:10.1002/ajmg.1320470421)

42 Hautanen A, Mänttäri M, Manninen V, Tenkanen L, Huttunen JK, Frick MH \& Adlercreutz H. Adrenal androgens and testosterone as coronary risk factors in the Helsinki Heart Study. Atherosclerosis 1994105 191-200. (doi:10.1016/00219150(94)90049-3)

43 Marques-Vidal P, Sie P, Cambou JP, Chap H \& Perret B. Relationships of plasminogen activator inhibitor activity and lipoprotein(a) with insulin, testosterone, 17 beta-estradiol, and testosterone binding globulin in myocardial infarction patients and healthy controls. Journal of Clinical Endocrinology and Metabolism 199580 1794-1798. (doi:10.1210/jc.80.6.1794)

44 Jeppesen LL, Jørgensen HS, Nakayama H, Raaschou HO, Olsen TS \& Winther K. Decreased serum testosterone in men with acute ischemic stroke. Arteriosclerosis, Thrombosis, and Vascular Biology 199616 749-754. (doi:10.1161/01.ATV.16.6.749)

45 Phillips GB, Pinkernell BH \& Jing TY. The association of hyperestrogenemia with coronary thrombosis in men. Arteriosclerosis, Thrombosis, and Vascular Biology 199616 1383-1387. (doi:10.1161/01.ATV.16.11.1383)

46 Price JF, Lee AJ \& Fowkes FG. Steroid sex hormones and peripheral arterial disease in the Edinburgh Artery Study. Steroids 199762 789-794. (doi:10.1016/S0039-128X(97)00103-7)

47 Tripathi Y \& Hegde BM. Serum estradiol and testosterone levels following acute myocardial infarction in men. Indian Journal of Physiology and Pharmacology 199842 291-294.

48 Zhao SP \& Li XP. The association of low plasma testosterone level with coronary artery disease in Chinese men. International Journal of Cardiology 199863 161-164. (doi:10.1016/S01675273(97)00295-7)

49 Kabakci G, Yildirir A, Can I, Unsal I \& Erbas B. Relationship between endogenous sex hormone levels, lipoproteins and coronary atherosclerosis in men undergoing coronary angiography. Cardiology $1999 \mathbf{9 2}$ 221-225. (doi:10.1159/ 000006977)

50 Chearskul S, Charoenlarp K, Thongtang V \& Nitiyanant W. Study of plasma hormones and lipids in healthy elderly Thais compared to patients with chronic diseases: diabetes mellitus, essential hypertension and coronary heart disease. Journal of the Medical Association of Thailand $2000 \mathbf{8 3} 266-277$.

51 English KM, Mandour O, Steeds RP, Diver MJ, Jones TH \& Channer KS. Men with coronary artery disease have lower levels of androgens than men with normal coronary angiograms. European Heart Journal 200021 890-894. (doi:10.1053/euhj. 1999.1873)

52 Dobrzycki S, Serwatka W, Nadlewski S, Korecki J, Jackowski R, Paruk J, Ladny JR \& Hirnle T. An assessment of correlations between endogenous sex hormone levels and the extensiveness of coronary heart disease and the ejection fraction of the left ventricle in males. Journal of Medical Investigation 200350 $162-169$.

53 Siemińska L, Wojciechowska C, Swietochowska E, Marek B, KosKudła B, Kajdaniuk D \& Nowalany-Kozielska E. Serum free testosterone in men with coronary artery atherosclerosis. Medical Science Monitor: International Medical Journal of Experimental and Clinical Research 20039 CR162-CR166.

54 Dunajska K, Milewicz A, Jedrzejuk D, Szymczak J, Kuliczkowski W, Salomon P, Bialy D, Poczatek K \& Nowicki P. Plasma adiponectin concentration in relation to severity of coronary atherosclerosis and cardiovascular risk factors in middle-aged men. Endocrine 200425 215-221. (doi:10.1385/ ENDO:25:3:215)

55 Dunajska K, Milewicz A, Szymczak J, Jêdrzejuk D, Kuliczkowski W, Salomon P \& Nowicki P. Evaluation of sex hormone levels and some metabolic factors in men with coronary atherosclerosis. Aging Male 20047 197-204. (doi:10.1080/ 13685530400004181 )

56 Fischer F, Schulte H, Mohan S, Tataru MC, Köhler E, Assmann G \& von Eckardstein A. Associations of insulin-like growth factors, insulin-like growth factor binding proteins and acid-labile subunit with coronary heart disease. Clinical Endocrinology 200461 595-602. (doi:10.1111/j.1365-2265.2004.02136.x)

57 Kajinami K, Takeda K, Takekoshi N, Matsui S, Tsugawa H, Kanemitsu S, Okubo S, Kitayama M \& Fukuda A. Imbalance of sex hormone levels in men with coronary artery disease. Coronary Artery Disease 200415 199-203.

58 Mikulec KH, Holloway L, Krasnow RE, Javitz H, Swan GE, Reed T, Marcus R \& Carmelli D. Relationship of endogenous sex hormones to coronary heart disease: a twin study. Journal of Clinical Endocrinology and Metabolism 200489 1240-1245. (doi:10.1210/jc.2003-031333)

59 Demirbag R, Yilmaz R, Ulucay A \& Unlu D. The inverse relationship between thoracic aortic intima media thickness and testosterone level. Endocrine Research 200531 335-344. (doi:10.1080/07435800500449494)

60 Davoodi G, Amirezadegan A, Borumand MA, Dehkori MR, Kazemisaeid A \& Yaminisharif A. The relationship between level of androgenic hormones and coronary artery disease in men. Cardiovascular Journal of Africa $2007 \mathbf{1 8} 362-366$.

61 He H, Yang F, Liu X, Zeng X, Hu Q, Zhu Q \& Tu B. Sex hormone ratio changes in men and postmenopausal women with coronary artery disease. Menopause 200714 385-390. (doi:10.1097/01. gme.0000235369.24479.dd)

62 Mohamad MJ, Mohammad MA, Karayyem M, Hairi A \& Hader AA. Serum levels of sex hormones in men with acute myocardial infarction. Neuro Endocrinology Letters 200728 $182-186$.

63 Turhan S, Tulunay C, Gülec S, Ozdöl C, Kilickap M, Altin T, Gerede M \& Erol C. The association between androgen levels and premature coronary artery disease in men. Coronary Artery Disease $2007 \quad \mathbf{1 8}$ 159-162. (doi:10.1097/MCA. Ob013e328012a928)

64 Debing E, Peeters E, Duquet W, Poppe K, Velkeniers B \& Van Den Brande P. Men with atherosclerotic stenosis of the carotid artery have lower testosterone levels compared with controls. International Angiology: a Journal of the International Union of Angiology 200827 135-141.

$65 \mathrm{Fu} \mathrm{L}$, Gao QP \& Shen JX. Relationship between testosterone and indexes indicating endothelial function in male coronary heart disease patients. Asian Journal of Andrology 200810 214-218. (doi:10.1111/j.1745-7262.2008.00335.x)

66 Page ST, Mohr BA, Link CL, O'Donnell AB, Bremner WJ \& McKinlay JB. Higher testosterone levels are associated with increased high-density lipoprotein cholesterol in men with cardiovascular disease: results from the Massachusetts Male Aging Study. Asian Journal of Andrology 200810 193-200. (doi:10.1111/j.1745-7262.2008.00332.x)

67 Fallah N, Mohammad K, Nourijelyani K, Eshraghian MR, Seyyedsalehi SA, Raiessi M, Rahmani M, Goodarzi HR, Darvish S, Zeraati H, Davoodi G \& Sadeghian S. Nonlinear association between serum testosterone levels and coronary artery disease in Iranian men. European Journal of Epidemiology 200924 297-306. (doi:10.1007/s10654-009-9336-9)

68 Cao J, Zou H, Zhu BP, Wang H, Li J, Ding Y \& Li XY. Sex hormones and androgen receptor: risk factors of coronary heart disease in elderly men. Chinese Medical Sciences Journal 201025 44-49. (doi:10.1016/S1001-9294(10)60019-3)

69 Cauley JA, Gutai JP, Kuller LH \& Dai WS. Usefulness of sex steroid hormone levels in predicting coronary artery disease in men. American Journal of Cardiology 198760 771-777. (doi:10.1016/ 0002-9149(87)91021-6)

70 Contoreggi CS, Blackman MR, Andres R, Muller DC, Lakatta EG, Fleg JL \& Harman SM. Plasma levels of estradiol, testosterone, and DHEAS do not predict risk of coronary artery disease in men. Journal of Andrology 199011 460-470.

71 Yarnell JW, Beswick AD, Sweetnam PM \& Riad-Fahmy D. Endogenous sex hormones and ischemic heart disease in men. The Caerphilly Prospective Study. Arteriosclerosis and Thrombosis: a Journal of Vascular Biology/American Heart Association 199313 517-520. (doi:10.1161/01.ATV.13.4.517) 
72 Khaw KT, Dowsett M, Folkerd E, Bingham S, Wareham N, Luben R, Welch A \& Day N. Endogenous testosterone and mortality due to all causes, cardiovascular disease, and cancer in men: European prospective investigation into cancer in Norfolk (EPIC-Norfolk) Prospective Population Study. Circulation 2007116 2694-2701. (doi:10.1161/CIRCULATIONAHA.107.719005)

73 Lehtonen A, Huupponen R, Tuomilehto J, Lavonius S, Arve S, Isoaho H, Huhtaniemi I \& Tilvis R. Serum testosterone but not leptin predicts mortality in elderly men. Age and Ageing 200837 461-464. (doi:10.1093/ageing/afn048)

74 Yeap BB, Hyde Z, Almeida OP, Norman PE, Chubb SA, Jamrozik K, Flicker L \& Hankey GJ. Lower testosterone levels predict incident stroke and transient ischemic attack in older men. Journal of Clinical Endocrinology and Metabolism 200994 2353-2359. (doi:10.1210/jc.2008-2416)

75 Corona G, Monami M, Boddi V, Cameron-Smith M, Fisher AD, de Vita G, Melani C, Balzi D, Sforza A, Forti G, Mannucci E \& Maggi M. Low testosterone is associated with an increased risk of MACE lethality in subjects with erectile dysfunction. Journal of Sexual Medicine 20107 1557-1564. (doi:10.1111/j. 1743-6109.2009.01690.x)

76 Rosano GM, Leonardo F, Pagnotta P, Pelliccia F, Panina G, Cerquetani E, della Monica PL, Bonfigli B, Volpe M \& Chierchia SL. Acute anti-ischemic effect of testosterone in men with coronary artery disease. Circulation 199999 1666-1670.

77 Webb CM, Adamson DL, de Zeigler D \& Collins P. Effect of acute testosterone on myocardial ischemia in men with coronary artery disease. American Journal of Cardiology 199983 437-439. (doi:10.1016/S0002-9149(98)00880-7)

78 English KM, Steeds RP, Jones TH, Diver MJ \& Channer KS. Lowdose transdermal testosterone therapy improves angina threshold in men with chronic stable angina: a randomized, double-blind, placebo-controlled study. Circulation $2000 \mathbf{1 0 2}$ 1906-1911.

79 Thompson PD, Ahlberg AW, Moyna NM, Duncan B, FerraroBorgida M, White CM, McGill CC \& Heller GV. Effect of intravenous testosterone on myocardial ischemia in men with coronary artery disease. American Heart Journal 2002143 249-256. (doi:10.1067/mhj.2002.120144)

80 Malkin CJ, Pugh PJ, Morris PD, Kerry KE, Jones RD, Jones TH \& Channer KS. Testosterone replacement in hypogonadal men with angina improves ischaemic threshold and quality of life. Heart 200490 871-876. (doi:10.1136/hrt.2003.021121)

81 Mathur A, Malkin C, Saeed B, Muthusamy R, Jones TH \& Channer K. Long-term benefits of testosterone replacement therapy on angina threshold and atheroma in men. European Journal of Endocrinology 2009161 443-449. (doi:10.1530/EJE09-0092)

82 Jadad AR, Moore RA, Carroll D, Jenkinson C, Reynolds DJ, Gavaghan DJ \& McQuay HJ. Assessing the quality of reports of randomized clinical trials: is blinding necessary? Controlled Clinical Trials 199617 1-12. (doi:10.1016/0197-2456(95) 00134-4)

83 Rosano GM, Sheiban I, Massaro R, Pagnotta P, Marazzi G, Vitale C, Mercuro G, Volterrani M, Aversa A \& Fini M. Low testosterone levels are associated with coronary artery disease in male patients with angina. International Journal of Impotence Research 200719 176-182. (doi:10.1038/sj.ijir.3901504)

84 Corona G, Mannucci E, Forti G \& Maggi M. Hypogonadism ED, metabolic syndrome and obesity: a pathological link supporting cardiovascular diseases. International Journal of Andrology 2009 32 587-598. (doi:10.1111/j.1365-2605.2008.00951.x)

85 Corona G, Rastrelli G, Morelli A, Vignozzi L, Mannucci E \& Maggi M. Hypogonadism and metabolic syndrome. Journal of Endocrinological Investigation 201134 557-567.

86 Corona G, Mannucci E, Fisher AD, Lotti F, Petrone L, Balercia G, Bandini E, Forti G \& Maggi M. Low levels of androgens in men with erectile dysfunction and obesity. Journal of Sexual Medicine $200852454-2463$.
87 Ding EL, Song Y, Malik VS \& Liu S. Sex differences of endogenous sex hormones and risk of type 2 diabetes: a systematic review and meta-analysis. Journal of the American Medical Association 2006 295 1288-1299. (doi:10.1001/jama.295.11.1288)

88 Corona G, Monami M, Rastrelli G, Aversa A, Sforza A, Lenzi A, Forti G, Mannucci E \& Maggi M. Type 2 diabetes mellitus and testosterone: a meta-analysis study. International Journal of Andrology, 2011 In press. (doi:10.1111/j.1365-2605.2010. 01117.x)

89 Bhasin S, Cunningham GR, Hayes FJ, Matsumoto AM, Snyder PJ, Swerdloff RS \& Montori VM. Task Force, Endocrine Society. Testosterone therapy in men with androgen deficiency syndromes: an Endocrine Society Clinical Practice Guideline. Journal of Clinical Endocrinology and Metabolism 201095 2536-2559. (doi:10.1210/jc.2009-2354)

90 Wu FC, Tajar A, Pye SR, Silman AJ, Finn JD, O’Neill TW, Bartfai G, Casanueva F, Forti G, Giwercman A, Huhtaniemi IT, Kula K, Punab M, Boonen S, Vanderschueren D \& European Male Aging Study Group. Hypothalamic-pituitary-testicular axis disruptions in older men are differentially linked to age and modifiable risk factors: the European Male Aging Study. Journal of Clinical Endocrinology and Metabolism 200893 2737-2745. (doi:10.1210/jc.2007-1972)

91 Kienitz T \& Quinkler M. Testosterone and blood pressure regulation. Kidney \& Blood Pressure Research 200831 71-79. (doi:10.1159/000119417)

92 Hughes GS, Mathur RS \& Margolius HS. Sex steroid hormones are altered in essential hypertension. Journal of Hypertension 19897 181-187. (doi:10.1097/00004872-19890300000003)

93 Svartberg J, von Mühlen D, Schirmer H, Barrett-Connor E, Sundfjord J \& Jorde R. Association of endogenous testosterone with blood pressure and left ventricular mass in men. The Tromsø Study. European Journal of Endocrinology $2004 \mathbf{1 5 0}$ 65-71. (doi:10.1530/eje.0.1500065)

94 Corona G, Mannucci E, Lotti F, Fisher AD, Bandini E, Balercia G, Forti G \& Maggi M. Pulse pressure, an index of arterial stiffness, is associated with androgen deficiency and impaired penile blood flow in men with ED. Journal of Sexual Medicine 20096 285-293. (doi:10.1111/j.1743-6109.2008.01059.x)

95 Corona G, Rastrelli G, Monami M, Melani C, Balzi D, Sforza A, Forti G, Mannucci E \& Maggi M. Body mass index regulates hypogonadism-associated CV risk: results from a cohort of subjects with erectile dysfunction. Journal of Sexual Medicine 20118 2098-2105. (doi:10.1111/j.1743-6109.2011.02292.x)

96 Tomlinson JW, Holden N, Hills RK, Wheatley K, Clayton RN, Bates AS, Sheppard MC \& Stewart PM. Association between premature mortality and hypopituitarism. West Midlands Prospective Hypopituitary Study Group. Lancet 2001357 425-431. (doi:10.1016/S0140-6736(00)04006-X)

97 Bojesen A, Juul S, Birkebaek N \& Gravholt CH. Increased mortality in Klinefelter syndrome. Journal of Clinical Endocrinology and Metabolism 200489 3830-3834. (doi:10.1210/jc.20040777)

98 Hamilton JB \& Mestler GE. Mortality and survival: comparison of eunuchs with intact men and women in a mentally retarded population. Journal of Gerontology 196924 395-411.

99 Shores MM, Matsumoto AM, Sloan KL \& Kivlahan DR. Low serum testosterone and mortality in male veterans. Archives of Internal Medicine 2006166 1660-1665. (doi:10.1001/archinte. 166.15.1660)

100 Keating NL, O'Malley AJ \& Smith MR. Diabetes and cardiovascular disease during androgen deprivation therapy for prostate cancer. Journal of Clinical Oncology 200624 4448-4456. (doi:10.1200/JCO.2006.06.2497)

101 Saigal CS, Gore JL, Krupski TL, Hanley J, Schonlau M, Litwin MS \& Urologic Diseases in America Project . Androgen deprivation therapy increases cardiovascular morbidity in men with prostate cancer. Cancer 2007110 1493-1500. (doi:10.1002/cncr. 22933) 
102 Tsai HK, D’Amico AV, Sadetsky N, Chen MH \& Carroll PR. Androgen deprivation therapy for localized prostate cancer and the risk of cardiovascular mortality. Journal of National Cancer Institute 200799 1516-1524. (doi:10.1093/jnci/djm168)

103 D'Amico AV, Denham JW, Crook J, Chen MH, Goldhaber SZ, Lamb DS, Joseph D, Tai KH, Malone S, Ludgate C, Steigler A \& Kantoff PW. Influence of androgen suppression therapy for prostate cancer on the frequency and timing of fatal myocardial infarctions. Journal of Clinical Oncology 200725 2420-2425. (doi:10.1200/JCO.2006.09.3369)

104 D'Amico AV, Chen MH, Renshaw AA, Loffredo M \& Kantoff PW. Causes of death in men undergoing androgen suppression therapy for newly diagnosed localized or recurrent prostate cancer. Cancer 2008113 3290-3297. (doi:10.1002/cncr. 23970)

105 Smith GD, Ben-Shlomo Y, Beswick A, Yarnell J, Lightman S \& Elwood P. Cortisol, testosterone, and coronary heart disease: prospective evidence from the Caerphilly Study. Circulation 2005 112 332-340. (doi:10.1161/CIRCULATIONAHA.104.489088)

106 Arnlöv J, Pencina MJ, Amin S, Nam BH, Benjamin EJ, Murabito JM, Wang TJ, Knapp PE, D'Agostino RB Sr, Bhasin S \& Vasan RS. Endogenous sex hormones and cardiovascular disease incidence in men. Annals of Internal Medicine 2006145 $176-184$.

107 Abbott RD, Launer LJ, Rodriguez BL, Ross GW, Wilson PW, Masaki KH, Strozyk D, Curb JD, Yano K, Popper JS \& Petrovitch H. Serum estradiol and risk of stroke in elderly men. Neurology 2007 68 563-568. (doi:10.1212/01.wnl.0000254473.88647.ca)

108 Vikan T, Schirmer H, Njølstad I \& Svartberg J. Endogenous sex hormones and the prospective association with cardiovascular disease and mortality in men: the Tromsø Study. European Journal of Endocrinology 2009161 435-442. (doi:10.1530/EJE09-0284)

109 Caminiti G, Volterrani M, Iellamo F, Marazzi G, Massaro R, Miceli M, Mammi C, Piepoli M, Fini M \& Rosano GM. Effect of long-acting testosterone treatment on functional exercise capacity, skeletal muscle performance, insulin resistance, and baroreflex sensitivity in elderly patients with chronic heart failure a double-blind, placebo-controlled, randomized study. Journal of the American College of Cardiology 200954 919-927. (doi:10.1016/j.jacc.2009.04.078)

110 Jankowska EA, Filippatos G, Ponikowska B, BorodulinNadzieja L, Anker SD, Banasiak W, Poole-Wilson PA \& Ponikowski P. Reduction in circulating testosterone relates to exercise capacity in men with chronic heart failure. Journal of Cardiac Failure 200915 442-450. (doi:10.1016/j.cardfail.2008. 12.011)

111 Isidori AM, Giannetta E, Greco EA, Gianfrilli D, Bonifacio V, Isidori A, Lenzi A \& Fabbri A. Effects of testosterone on body composition, bone metabolism and serum lipid profile in middleaged men: a meta-analysis. Clinical Endocrinology 200563 280-293. (doi:10.1111/j.1365-2265.2005.02339.x)

112 Whitsel EA, Boyko EJ, Matsumoto AM, Anawalt BD \& Siscovick DS. Intramuscular testosterone esters and plasma lipids in hypogonadal men: a meta-analysis. American Journal of Medicine 2001111 261-269. (doi:10.1016/S00029343(01)00833-6)

113 Corona G, Monami M, Rastrelli G, Aversa A, Tishova Y, Saad F, Lenzi A, Forti G, Mannucci E \& Maggi M. Testosterone and metabolic syndrome: a meta-analysis study. Journal of Sexual Medicine 20118 272-283. (doi:10.1111/j.1743-6109.2010. 01991.x)

114 Haddad RM, Kennedy CC, Caples SM, Tracz MJ, Boloña ER, Sideras K, Uraga MV, Erwin PJ \& Montori VM. Testosterone and cardiovascular risk in men: a systematic review and metaanalysis of randomized placebo-controlled trials. Mayo Clinic Proceedings 200782 29-39. (doi:10.4065/82.1.29)

115 Fernández-Balsells MM, Murad MH, Lane M, Lampropulos JF, Albuquerque F, Mullan RJ, Agrwal N, Elamin MB, GallegosOrozco JF, Wang AT, Erwin PJ, Bhasin S \& Montori VM. Clinical review 1: adverse effects of testosterone therapy in adult men: a systematic review and meta-analysis. Journal of Clinical Endocrinology and Metabolism 201095 2560-2575. (doi:10. 1210/jc.2009-2575)

116 Hyde Z, Flicker L, Almeida OP, Hankey GJ, McCaul KA, Chubb SA \& Yeap BB. Low free testosterone predicts frailty in older men: the health in men study. Journal of Clinical Endocrinology and Metabolism 201095 3165-3172. (doi:10. 1210/jc.2009-2754)

117 Basaria S, Coviello AD, Travison TG, Storer TW, Farwell WR, Jette AM, Eder R, Tennstedt S, Ulloor J, Zhang A, Choong K, Lakshman KM, Mazer NA, Miciek R, Krasnoff J, Elmi A, Knapp PE, Brooks B, Appleman E, Aggarwal S, Bhasin G, HedeBrierley L, Bhatia A, Collins L, LeBrasseur N, Fiore LD \& Bhasin S. Adverse events associated with testosterone administration. New England Journal of Medicine 201036 3109-3122.

118 Srinivas-Shankar U, Roberts SA, Connolly MJ, O'Connell MD, Adams JE, Oldham JA \& Wu FC. Effects of testosterone on muscle strength, physical function, body composition, and quality of life in intermediate-frail and frail elderly men: a randomized, doubleblind, placebo-controlled study. Journal of Clinical Endocrinology and Metabolism 201095 639-650. (doi:10.1210/jc.20091251)

119 Kjaergaard AD, Ellervik C, Tybjaerg-Hansen A, Axelsson CK, Grønholdt ML, Grande P, Jensen GB \& Nordestgaard BG. Estrogen receptor alpha polymorphism and risk of cardiovascular disease, cancer, and hip fracture: cross-sectional, cohort, and casecontrol studies and a meta-analysis. Circulation $2007 \mathbf{1 1 5}$ 861-871. (doi:10.1161/CIRCULATIONAHA.106.615567)

120 Shearman AM, Cupples LA, Demissie S, Peter I, Schmid CH, Karas RH, Mendelsohn ME, Housman DE \& Levy D. Association between estrogen receptor alpha gene variation and cardiovascular disease. Journal of the American Medical Association 2003 290 2263-2270. (doi:10.1001/jama.290.17.2263)

121 Kunnas TA, Laippala P, Penttilä A, Lehtimäki T \& Karhunen PJ. Association of polymorphism of human alpha oestrogen receptor gene with coronary artery disease in men: a necropsy study. British Medical Journal 2000321 273-274. (doi:10.1136/bmj. 321.7256.273)

122 Shearman AM, Cooper JA, Kotwinski PJ, Humphries SE, Mendelsohn ME, Housman DE \& Miller GJ. Estrogen receptor alpha gene variation and the risk of stroke. Stroke 200536 2281-2282. (doi:10.1161/01.STR.0000181088.76518.ec)

123 Jankowska EA, Rozentryt P, Ponikowska B, Hartmann O, Kustrzycka-Kratochwil D, Reczuch K, Nowak J, Borodulin-Nadzieja L, Polonski L, Banasiak W. Poole-Wilson PA, Anker SD \& Ponikowski P. Circulating estradiol and mortality in men with systolic chronic heart failure. Journal of the American Medical Association 2009301 1892-1901. (doi:10.1001/jama.2009.639)

124 Angstwurm MW, Gaertner R \& Schopohl J. Outcome in elderly patients with severe infection is influenced by sex hormones but not gender. Critical Care Medicine 200533 2786-2793. (doi:10. 1097/01.CCM.0000190242.24410.17)

125 Giagulli VA, Kaufman JM \& Vermeulen A. Pathogenesis of the decreased androgen levels in obese men. Journal of Clinical Endocrinology and Metabolism 199479 997-1000. (doi:10. $1210 /$ jc. 79.4 .997$)$

126 Vermeulen A, Kaufman JM, Deslypere JP \& Thomas G. Attenuated luteinizing hormone (LH) pulse amplitude but normal LH pulse frequency, and its relation to plasma androgens in hypogonadism of obese men. Journal of Clinical Endocrinology and Metabolism 199376 1140-1146. (doi:10.1210/jc.76.5.1140)

127 Yadid G, Sudai E, Maayan R, Gispan I \& Weizman A. The role of dehydroepiandrosterone (DHEA) in drug-seeking behavior. Neuroscience and Biobehavioral Reviews 201035 303-314. (doi:10.1016/j.neubiorev.2010.03.003)

128 Yen SS. Dehydroepiandrosterone sulfate and longevity: new clues for an old friend. PNAS 200198 8167-8169. (doi:10.1073/ pnas.161278698)

129 Buvat J. Androgen therapy with dehydroepiandrosterone. World Journal of Urology 200321 346-355. (doi:10.1007/s00345003-0367-7) 
130 Barrett-Connor E, Khaw KT \& Yen SS. A prospective study of dehydroepiandrosterone sulfate, mortality, and cardiovascular disease. New England Journal of Medicine 1986315 1519-1524. (doi:10.1056/NEJM198612113152405)

131 Legrain S, Berr C, Frenoy N, Gourlet V, Debuire B \& Baulieu EE. Dehydroepiandrosterone sulfate in a long-term care aged population. Gerontology $1995 \mathbf{4 1}$ 343-351. (doi:10.1159/ 000213706)

132 Tilvis RS, Kähönen M \& Härkönen M. Dehydroepiandrosterone sulfate, diseases and mortality in a general aged population. Aging 199911 30-34.

133 Feldman HA, Johannes CB, Araujo AB, Mohr BA, Longcope C \& McKinlay JB. Low dehydroepiandrosterone and ischemic heart disease in middle-aged men: prospective results from the Massachusetts Male Aging Study. American Journal of Epidemiology 2001153 79-89. (doi:10.1093/aje/153.1.79)

134 Kähönen MH, Tilvis RS, Jolkkonen J, Pitkälä K \& Härkönen M. Predictors and clinical significance of declining plasma dehydroepiandrosterone sulfate in old age. Aging 200012 308-314.
135 Sanders JL, Boudreau RM, Cappola AR, Arnold AM, Robbins J, Cushman M \& Newman AB. Cardiovascular disease is associated with greater incident dehydroepiandrosterone sulfate decline in the oldest old: the cardiovascular health study all stars study. Journal of the American Geriatrics Society $2010 \mathbf{5 8} 421-426$. (doi:10.1111/j.1532-5415.2010.02724.x)

136 Aversa A, Bruzziches R, Francomano D, Rosano G, Isidori AM, Lenzi A \& Spera G. Effects of testosterone undecanoate on cardiovascular risk factors and atherosclerosis in middle-aged men with late-onset hypogonadism and metabolic syndrome: results from a 24-month, randomized, double-blind, placebocontrolled study. Journal of Sexual Medicine 20107 3495-3503. (doi:10.1111/j.1743-6109.2010.01931.x)

Received 17 May 2011

Revised version received 16 July 2011

Accepted 18 August 2011 